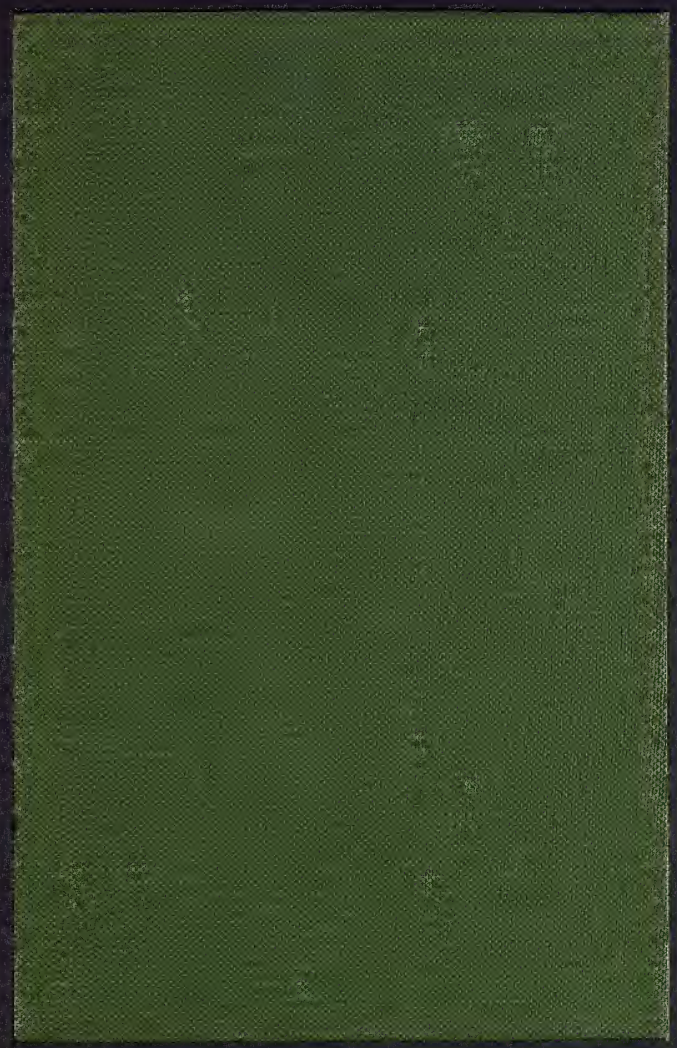

Printed image digitised by the University of Southampton Library Digitisation Unit 


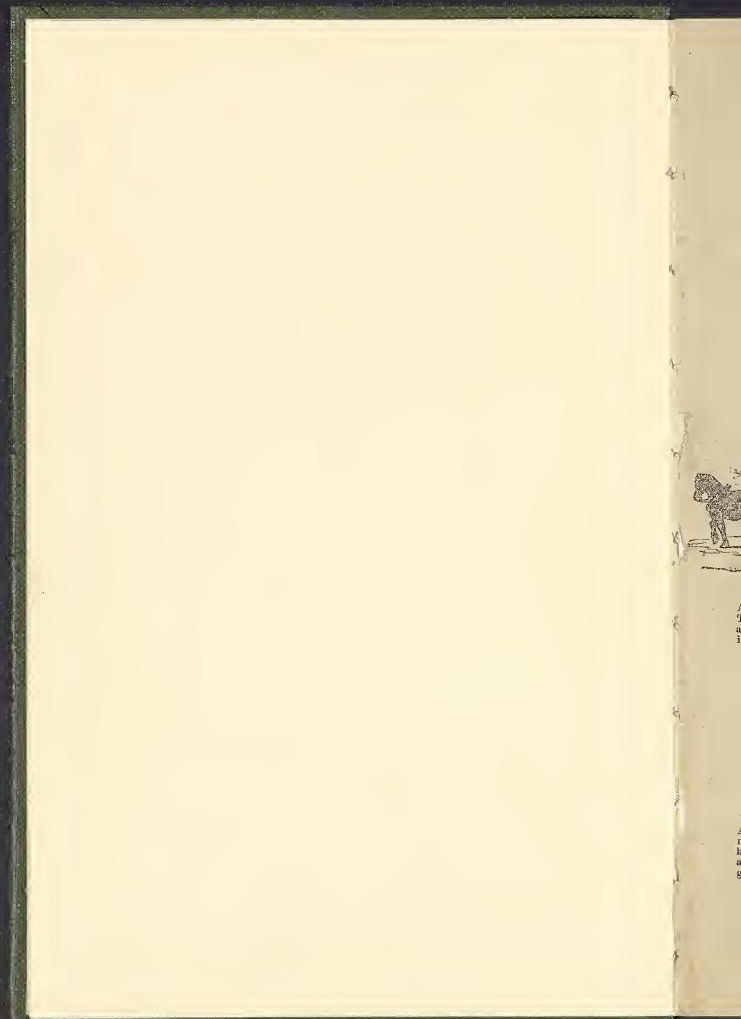

Printed image digitised by the University of Southampton Library Digitisation Unit 


\title{
A LETTER
}

To

\section{THE FARMERS OF ENGLAND,}

ON THE TELATIONSHIP OY

\author{
MANUFACTURES AND AGRICULTURE.
}

\section{BY ONE WHO HAS WHISTLED AT THE PLOUGH.}

Author of Letters weder that Signature in "The Morning Chrowiole."

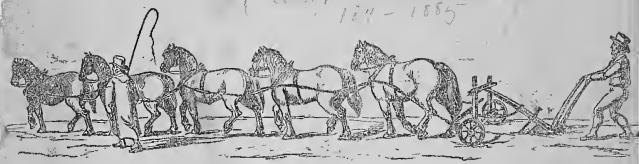

A PLover as seen at work in Bnelkinghamshire, in 1842. The soil a stiff clay, mameliopated bỳ science. A PLOJGr as seen at work th Bnes the lioutid mannres utterly neglected; fences bad; fields fonl with wépls: The solid manures wasted in the sun; the figuid masnures uaterly neglected; The farmer, a tenent-at will, puying, is little eeonomy in every department of the larm as in that of the plough. The farmet, a tenent-at will, puying, less than 60s., to par his expenaes, Belioves the repeal of the Corn Jaws would ruin him.

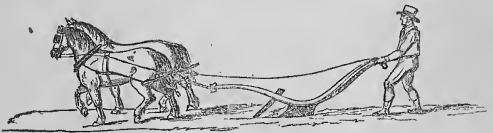

A prover as used in the Lothians of Seotlend. When the soil is a stifi elay, it is ameliorated by other

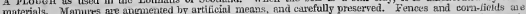
materials, Manures ase angment is observed in all kinds of labour, while morepeopla are employed foreats kept in the best onler; mid eanony is obserked in teil kinds of iabour, while morepeopla are employed foreats gre thin in 1841 , they paid from $f t$ to $f(t$ per acre. If they peid the same reat for the same quality of laxd as hi Backinghunhire, they eould sell wheat at tus. a quarter, and have a good profit.

\section{LONDON :}

JAMES RIDGWAY, PICCADILLY.

1843. 


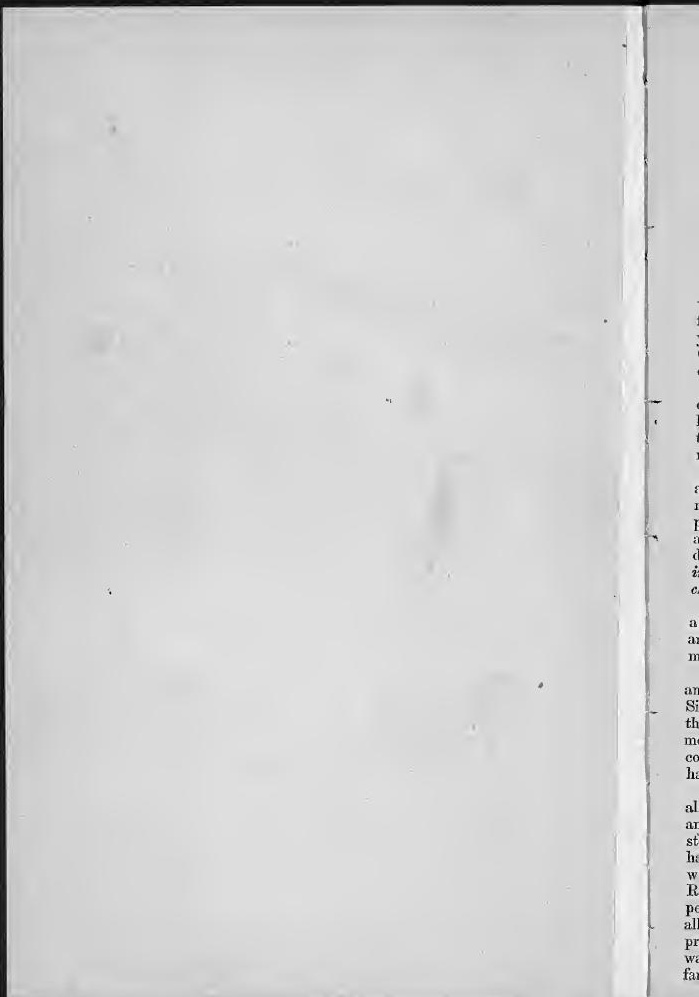

Printed image digitised by the University of Southampton Library Digitisation Unit 


\section{FARMERS OF ENGLAND.}

Gentuemen,-The writer of this letter has recently visited and conversed with many of you in different counties; in your market towns, on your farms, at your dinner tables, and at your family fire-sides. $\mathrm{He}$ has hoard you, whether corn-growers or grazicrs, Icase-holders or tenants-at-will, Conscrvatives or Libcrals, politicians or non-politicians, expressing your dissatisfaction with your present condition.

You are not dissatisficd without cause. Something has lowered the value of your live stock and harvest crops, and you know that though the season has been generally farourable, neither the supcrior quality of the stock nor the abundanee of the harvest has caused this fall in prices. All of you, to a man, are agreed on this point.

Some of you say the ncw tariff has becn the cause, and you argue that although the importations from forcign countries have not amounted to much, compared with your own supply, the mere fact of an importation has produced a panic, and this panic has unsettled the business of the grazier, and redued his prices. Those of you who blame the panic are in some degree right: all of you should blame it. But panies will follow every change in the scale of protective duties; and so long as these duties exist there will be changes, no matter who may be prime minister.

Some of you, again, blame the sliding-scale which throws into the market a large quantity of foreign grain just at that period, when, of all others, you are most in want of protection, the period of taking your new crops to market to pay your Michaclmas rents.

Others, without taking duc notice of the laws affecting your prosperity, and the causes of those laws, merely rail at certain men. One denounces Sir Robert Pecl as a traitor to your interests; another defends him, and says, the fault lies with Lord John Russell and the Whigs, who, having dared to meddle with the protective duties, left behind them a legacy of popular discontent, which compelled Sir Robert Peel to do what otherwise he would not
have done:

Gentlemen, put your faith in nobody. If possible, detach yourselves from all political parties, and attend to your own interests. Proceed at once to an investigation of those causcs which have reduecd the value of your live stock and corn, which have staggered you with cheapness, while the scason las not overwhelmed you with plenty. You will find that neither the tariff with its panic, nor the large influx of foreign corn at harrest time, nor Sir Robert Peel, nor Lord John Russell, nor any other single circumstance, nor person, nor party, is exclusivoly the source of the present difficultics. Nay, all these combined are not the souree. You will find the main cause of your present dull markefs in the stagnation of our manufacturing trade, in the want of employment on the part of those millions who buy and consume your farm produce. 
What do you, corn-growers of Kent and Esscx, and other corn counties, do with your wheat? And you, grazicrs of Dorset, and Devon, and Cheshire, what do you do with your butter and cheese? You sell in the market towns; and dealers in market towns send your coris, and butter, and checse to other towns, until we find that corn-growing and butter-making counties supply the food of cotton-spinning and cloth-making counties. Here, then, we come to your customers, to the consumers of your farm produce, corn, butter; cheese, beef, mutton and bacon. If these consumers of your produce are without work and wages, or if work and wages are reduced one-third, they must either be on workhouse diet or starving, or they must be consuming one half less of your corn, butter, cheese, beef, mutton, and bacon. This is so self-evident that you need not be told of it. But you need to be told the extcnt of the want of employment and the reduction of wages. Your local newspaper seldom gives you information on this point. It professes to be your best friend and guide, but if it is a paper in the interest of the landowners, it commonly conceals from you the extent of your dependance on the manufacturing'interests, and the extent of manufacturing porerty. At all events it hides from you the character and causes of that poverty. Nay, it will perhaps tell you that British agriculture would flourish, and Britain remain as great a country as she is, were her manufacturing towns, steamengines, looms, and cotton warehouses swept into the sea. This might be, if you could sell your farm produce to some one who would pay you for it and throw it into the sea. Such ideas are monstrously absurd, yet they have found utterers in the persons of some who profess to be your friends. Let us leave such folly and such fools; and, adhering to facts and figures of truth, let us see where the dulness of your corn and cattle markets begins.

We have not, at present, sufficient information on which to found a description of all the manufacturing towns, neither have we space in a small pamphlet to notice all that we are correctly informed of. But the following are fair specimens. The spring and summer of 1842 is the period to which the figures refer, if not otherwise stated :-

AsmTon-UNDER-LYNe.--Eight mills standing idle. At least 2,000 persons - out of work, and the wages of those employed reduced 17 per eent.

Accrington. - Population 8,719. Fmployment, calico printing and cotton trade. Number of workers, 3,738 , of whom 1,389 are fully employed at an average of 8 s. $8 d$. per week; 1,622 partly employed at an average of $4 s$. $10 d$. per week; and 727 unemployed and destitute. At one of the print works the following statement is made by the master:In 1836 he paid 80 block printers $3,524 l$. $14 \mathrm{~s} .6 d$. $;$ in 1810 he paid the same men $1,247 \mathrm{l}$. $12 \mathrm{~s} .6 \mathrm{~d}$.; averaging in $1836,17 \mathrm{~s}$. each per week; in 1841 , not quite $6 \mathrm{~s}$. each per week.

Need you be told, farmers of England, that with 178 . a week therc would be loaf-bread, and butcher-meat, and cheese, and buttcr used, while with $6 \&$. there can be little more than oatmeal gruel, potatoes and salt?

Aввиолтн, a town in Scotland. Population, 14,591. Trade, flax-dressing, spinning, weaving, shipping, \&c. Wages rednced 24 per cont. since 1836 . One-third of the population unemployed. The consumption of wheaten bread, butcher-meat, butter, and checse, has fallen further than in proportion to wagcs and employment. Potatoes and oatmeal have displaced other articles, which are comparative luxuries.

Aвendsen, a town in Scotland. Populatiou about 60,000. Trade, fiax-spinning, weaving, shipping, \&c. Fxports to America, in 1834, 5,221 tons; in 1840, 2,320 tons. In 1842 much shipping laid up; sea stores of beef and biscuit not required to the usual extent by one-third. Several mills stopped, hands thrown out of work; poor rates doubled in one parish ; consumption of butcher-meat greatly diminished. Graziers and butchers send more meat, in consequence, to Londen to overstock the markets there, and compete with the farmers of the south. 
Barnstex, a town in Yorkshire, in the linen mañufacture. Since 1838,16 masters have failed, whose united liabilities amounted to 296,500 . Ten more have retired from business, having lost $30,000 l$. In 17 shops, containing 60 looms, when trade was good, say fromi 1833 to 1838 , each loom earned $7 s_{+} 7 d$. per week; now the earnings are $4 s .94 d$. per week : difference, $25.9 \frac{\pi}{2} d$. In the years 1833,1834 , and 1835 , the number of pieces finished at the principal calender was 168,441 . In the years 1839,1840 , and 1841 , the number of pieces finished at the same was 114,131 . The other finishing calenders showing a similar deficiency.

Here again the farmer may see why his cattle and sheep, and butter and cheese, lie heavy on his hands.

Ballnow, a township in Yorkshire. "Trade, woollen cloth. Fifteen spinners; manufacturers and shopkeepers have failed within a short period. The consumption of animal food is considerably decreased; many substitute potatoes of inferior quality for bread. Small shopkeepers' bnsiness is much rednced (those are the retailers of the butter, cheese, bread, and bacon produce of the English farmers), and they can with difficulty obtain payment for what they sell.

Barxarn Castre, a town in Dnrham. Trade, carpet weaving. One half of operatives unemployed; the remainder paid reduced wages. Consumption of bread and butchermeat reduced to a merely nominal amount.

Bisanforn, a town in Yorkshire, in the woollen cloth and worsted trades. Thirty-six mills employing 1,200 horse power; 22 running full time, paying 30 per cent. less in wages than when trade was good; 10 running short time, and 4 standing. Forty per cent. of the working population of all trades out of work. Nechanics (employed by machiue makers) formerly earning $24 s$. to 30 s. per week, are now jobbing or breaking road stones. Handloom weavers are not half of them in full work. Nearly all the mills employed in worsted spiuniug are running short time, or have part of their machinery standing. Poor-rates are increasing at fully 1,300 . per quarter.

And, farmers of England, do you not see and feel that the bad trade in those towns throws a surplus population back on you to increase your poorrates? this in addition to the non-consumption of your farm produce.

BRAdrord, a town in Wiltshire. Population, 8,309. Trade, woollen cloth manufacture. There are 462 broad cloth looms, of which 316 are idle, and only 11 fully employed. When trade was good, the quantity of meat and bread consumed was fonr timesi $t$ s present amount.

Botmon, a town in Lancashire, in the cotton trade. In Deeember, 1841, ont of 50 mills, which, when at full work, gave employment to 8,124 persons, 30 were either standing idle or working short time. In 1836 , the number of iron-founders, engineers, millwrights, and machine-makers employed was 2,110 ; in 1842 the total number cmployed was 1,325 . Difference of unemployed in these four trades 785, who, with their families, are either returming to the rural districts to swell the poor-rates patd by farmers, or are starving in towns, unable to buy food, and are preventing those young men who annually leave the country for a town life from leaving lome, which young men will soon overcrowd the rural parishes, already fnll enough. In 1836 the number of carpenters employed in Bolton was 150. In 1842, 49 are employed, and 1.01 entirely idle. The number of bricklayers em. ployed in 1837 was 120 ; at present $16 ; 104$ idle. Stone masons employed in 1836, 150 ; at present 50: 100 unemployed and suffering severely. Tailors employed in 1836, 500; 250 unemployed at present, and the remainder only partially employed, at reduced wages. Shoemakers (of the society) 80 in 1836 employed; 40 at present, and these only partially, and at reduced wages. The entire loss to 5,000 factory hands, who are either wholly unemployed, or working short time, is computed at 1,250i. per week, which, with the loss to the trades already named, amonnts to $3,300 l$. per week, or $171,600 l$, per year. Taking these trades at this sum, (which is rather under the actual anonut,) and adding for those branches of industry not estimated $30,000 l$., we have a loss in wages in Bolton alone of 201,600l. Two hundred and one thonsand six hundrod prunds sterlingl Two-thirds of which would have gone directly to the provision shops aud the meat market, and most of the other third of which would have gone to pay rents, not now paid, and buy clothes, not now bought, to and from those who wust at present eat their meat and bread and buttex and cheese according to their reduced incomes. In the year ending March 1836, the sum paid for the'relief of the poor in Bolton was 1,558l. 9s. 6d.; the year ending March 1841, it was $6,268 l$. $15 \mathrm{~s} .4 d$. 
Can the farmers of England read such facts and be at a loss to aeeount for their dull markets?

One word more about Bolton. It has been asserted by landed gentlemen, both in and out of Parliament, and by newspapers under their patronage, that the interesis of agrieulture and manufactures are distinct, and that the land would maintain its value if there were no manufactures. The land in the division of Bolton was rented 150 years ago, according to figures shown by the land-tax, at $5,127 \mathrm{l} .168 .8 \mathrm{~d}$. The present rental of this division was estimated and put down last year for the county rate at the sum of $491,695 l$., showing an inerease which has chiefly arisen within these seventy years, through manufacturing skill and industry, of $9,589 l$. per cent. The Chorlton estate near Manchester is an extraordinary instanee. In 1644 it was sold for $300 l$. In 1794, it was sold for $42,914 l$. Last year it was assessed at 137,651 $l$. per annum, having inereased in less than two centuries from $300 l$. to upwards of $3,000,000 l$. in net value!

Burx, a town in Lancashire, in the cotton and machine-making trade. Wages paid by one machine-making establishment in 1836, 45,453l., and in $1841,23,804 l$., and the reduction is still going on. Difference, full one-half of which is lost to the English farmer, 21,649 . This is bul in one establishmenl of one trade, in one town. The number of families visited in Bury for the purpose of acquiring these statistical facts, was 776, containing 3,982 persons; of these only 1,107 are employed, whose average earnings are only about $3 \frac{1}{6} d$. per day.

What $a$ tale does this tell for beef and mutton, and bacon and butter and cheese. All the cattle imported under the new tariff, and all the salted provisions, do not amount to as mueh, up to the time of writing this statement (November, 1842) as the towns of Bury and Bolton consumed when their population was in full employment. But let us proeeed.

Birminghan,-Population, 138,187 . In the silver-working trade the men are not employed, on an average, more than three or four days a week, and their wages have fallen considerably since 1835 . The coal and iron trade has fallen of one-half in most cases. In the most favourable cases it is not more than two-thirds as much as it was in cases. In the most farourable cases it is not more than two-ther of hands employed as brass-foumders has been reduced one-half, and the wages of the remaining half who are at work have been reducod two-thirds.

Mark that, farmers of England; one half of the brass founders out of employment and the remaining half paid two-thirds less than the wages paid when the wholc were employed working full time, and eating of bread, buteher-meat, butter and cheese full meals. Here is a town where manufacturing by maehinery eannot be urged as a eause of over-production and a displacement of workmen, as is sometimes alleged, by those who do not know that an inerease of maehinery, taking the entire population of the country, has inereased, to a vast extent, the employment of human hands.

In the plating trade there has been a reduction of one-third of the numbers employed, and their wages reduced 35 to 40 per cent. The screw-makers in 1835 and 1836 got $1 s .9 d$. for making the same article which now pays them $9 d$. only.

Brechen, a town in Scotland. Population, 5,097. Trade, flax-dressing and spinning. Wagcs of spinners reduced one-sixth since 1836 of flax-dressers rednced onc-fifth in the same time. A rcduction still going on, the whole of which falls on the consumption of the best kinds of food, such as butcher-meat.

Chaутos.-In the Yorkshire woollen trade. Popnlation, 4,347. Two ont of three worsted factories unoccupied. Poor.rate for a cottage in 1836, 4s. $6 d$. per anmum; in $1842,15 \mathrm{~s}$, per annum.

CoLNe, a town in Laneashire, in the cotton trade. Population, 20,648. Money wages in 1841,35 per cent. less than in 1831 . There are fully employed 964 persons, earning $5 s$. a week; partially cmployed, 1,604; unemployed, 2,355 . From an inquiry lately instituted by the Bosrd of Guardians, it appeared that 8,686 persons had only an income averaging 1s. $4 d$. per week, including the parish relief, which averaged $3 d$. per head. 
CARLI8LE, the capital and principal market town of Cumberland, with several cotton factories. There are 309 families, comprising 1,146 persons, who have no ascertainable income; 334 families, comprising 1,465 persons, whose income is less than 18 . per head a week; 411 families, compriking 1,623 persons, whose income is less than $1 \mathrm{~s}$. 6d.; 157 families, comprising 692 persons, with an income of less than $2 s . ;$ and 140 families, comprising 635 persons, whose income is less than $3 s$. per head a week.

Cotentry, a town in Warwickshire, in the ribbon trade. Two tbousandfive hundred are recipients of charity; many more are without employment, and the wages of those in work have been reduced 80 per cent.

DERBY, a town in the silk hosiery trade. Population, 35,015. In 1836 there were 760 silk frames fully employed; at present there are 346 but partially employed, and 392 standing. The wages iu 1836 for a man and woman were 25 s., at present 12 s.

Is there any wonder that the beef and bacon and dairy produce of the farmers should meet a dull market?

DunfekmLIne, a town in Scotlaud. Trade, damask weaving (flowered table-cloths, and such like): no power looms to compete with. Population, 13,323. Wages reduced 25 per cent. since 1836. Five hundred and eighty-five weavers unemployed in the spring of this year. In November, while this is being written, the unemployed are 1,780 , and daily increasing, with some of the oldest masters becoming bankrupt.

Dundes, a large town in Scotland. Popnlation 59,135. Trade, flax-dressing, spinning, sailcloth, shipping, \&c. When shipping is laid up, and the demand for sail-cloth and rigging falls off, the farmer may be sure that the demand for provisions will fall off also. The consumption of animal food in Dundee was doublo in 1836 to what it was in 1841. But the large steamers which trade from Dundee to Lond on have conveyed many more cattle and sheep, and earcases of killed meat, to the metropolitan markets since the decay of trade than they did before. All that which is not consumed in Dundee is sent to London to compete with the southern farmer, whose Cheshire and Gloucester cheese the Dundee people cannot buy in return as they once did. Of factory hands, 1,319 -are employed, 360 of them on government sail-cloth, the contracts for which are about madc up, (this in the spring of 1842); 554 are partially employed; and 1,458 are without work or wages of auy kind. Average number of mechanics employed by machine makers when trade was good, 1,638; total number now employed, 758 ; unemployed, 880 . Number of stone-masons employed in neighbouring quarries by six of the most extensive contractors, 405 ; number recently employed, 66; unemployed, 339. All the other trades, slaters, plumbers, plasterers, shipwrights, earpenters, tailors, shoemakers, \&c., are in a similar condition, and all were consumers of butcher-meat when trade was good.

Edinaureh, the capital of Scotland, which, with the shipping port of Leith, and other adjoining towns, contains about 200,000 inhabitants. The trades carried on are various; but in all branches the reduction of wages and the failure of employment has been great within the last two years. Small shopkeepers are becoming bankrupt, and the higher class of tradesmen are paying family expenses and rents out of capital, not from profits. Thousands of people who once used butcher-meat, are now restrained to the use of potatoes.

Forp $A$ r, a town in Scotland, with a population of 8,000 , (within the parliamentary boundaries), chiefly connected with weaving. Of 1,402 families visited, comprising 5,122 individuals, 139 have only from $6 d$. to $9 d$. a day; 193 from $5 d$. to $5 \frac{3}{4} d .: 368$ from $4 d$. to $4 \frac{3}{4} d . ; 851$ from $3 d$. to $3 \frac{\pi}{4} d . ; 1,533$ from $2 d$. to $2 \frac{3}{4} d$.; 1,922 from $\frac{3}{4} d$. to $1 \frac{3}{4} d$. a day ; and 118 are dependant entirely on charity. In 1836 a weaver could earn $108.6 \mathrm{~d}$. a week; and now his wages for the same work are only 6s. 6d. In 1836 nore than twice the number of cattle were killed than in' 1841 .

Mark that, graziers of England; the cattle not killed and consumed in Scotland find their way to Smithfield.

Forest-or-Dean.-This is a mining district. Workmen have lately had but half work 3 wages reduced 50 per cent.

Frome, a town in Somersetshire. Population, 11,279, being a decrease since 1831 of 921. Trade, woollen cloth. Of 28 mills, 20 are partially employed, 5 standing, and 3 eonverted to other purposes. One-sixth of the honses uninhabited, and rents reduced 50 per cent. The consumption of butcher-meat, \&c., reduced in like proportions.

HoLmpirth. - The wages of the weavers of kerseys, \&c., were in 1833, 16s. 10d.; 1834 17s. 6d.; 1835, 17s. 7d.; 1839, 13s. $8 \frac{1}{2} d . ; 1840,12 s .1 d . ; 1841,9 s$ 6d., and are till falling; and the consumption of farm produce falling with them. 
Hamfix, a town, in the Yorkshire woollen trade. Sixty-four families broken up and gone into lodgings. Nine hundred and forty-two persons unemployed; 743 partially employed, and wages reduced 25 to 30 per cent.

Hinckezy, a town in Leiccstershire, in the hosiery trade. One-third of the workmen are wholly withont employment, and 500 lieads of families are in the workhonse.

K BNDAI, a town in Westmoreland. Population, 11,700. Trade, woollen manufaetures. The uumber of piees exported to America have fallen from 33,000 to less than 1,000 per anmum. The reduetion in the amount of wages paid since 1837 has been computed at 15,860l. per annum, one half of which is a loss to the Inghish farmer.

Kirrismuin, a town in Forfarshire, Scotland. Population, 7,000, chiefly handloom weavers. The consumption of butcher-meat has fallen 60 per cent. In 1836,10 cattle were killed for this market week]y, now there are only four killed.

Here is a differenee of six eattle in a little town of whieh, probably nine-tenths of Englishmen never heard the name before. Were these six eattle, not now used in Kirriemuir, but sent to London from Dundee or Aberdeen, to eome from some shipping port on the continent, we would have their arrival proelaimed in all the newspapers, and graziers would eomplain of the New Tariff; the panie would spread, and six fat cattle a week from one foreign port would be looked on as a serious inroad on the rights of the British farmer; at all events the fat six would fill a respeetable plaee in the columns of the farmers' newspaper. Yet here they are from one little Seotch town, beeause the weavers eannot afford to eat them at home, and the Finglish farmer lnows nothing of the matter, neither of their arrival nor the eause of their eoming. It is time he did know ; and it is time he knew the eause, and the eauses of that eause. He must see-by this time that the manufaeturing interests are his interests. Let us, however, proeeed with the evidenee.

Kinmannoer, a town in the west of Scotland. Population, 19,398. The trade chiefly worsted manufacture. Nine hundred and four persons unemployed, on whou are dependant 1,117 others. Wages rednced 20 to 30 per cent.; poor-rates increased 50 per cent. during these last three years. The consumption of butcher-meat, butler, and cheese, has in like manner fallen off.

Lress, a great town in Yorkshire, in the woollen, flax, and machine-making trades. It may be proper to remark, that Leeds is the eentre of a great district of towns, which for the sake of space me cannot particularly notice here. They are all in the same condition; therefore the description of Leeds is suitable for all. The consumption of butehermeat and groceries has fallen off since 1836 full one-fourth. The managers of the Albion Mill Company estimate that if the wages and the amount of employment had been the same in 1841 as in 1835 , they would have paid $11,960 l$. in wages, instead of which they paid only 4,784l. During the last seven or eight years, 56 of the first class grocers have failed, or gone out of business, or died leaving no property behind them; and there are only 12 who have been in the trade apwards of eight years and who have not failed. Of the second class of grocers, 240 have either failed or gone out of business in the same period. The latter fact tells the condition of the working population, who run up accounts with the smaller grocers. From the year 1838 to 1841,29 houses engaged in the woollen trade in the township of Leeds became insolvent, whose united liabilities amounted to 515,000t., and there have been in the same time 10 cloth-finishers aud others in comnexion with the woollen tracle insolvent. In the flax and tow.spinning trade, 18 houses have become insolvent. Among machine-makers, 16 have failed. Of wool-staplers, only 3 failed from 1833 to 1837 , and 3 went out of the trade; sinee 1837 to $18+1,16$ have failed and 16 gone out of the trade. Of stuff houses and worsted spinners, 9 have failed. The liabilities of all these insolveuts amount in the whole to $1,451,000 l$.; and if the failures in the towns adjoining Leeds are added, the sum will be apwards of $2,000,000 l$. Some capitalists may have prosperad among the general wreck, but their gains cannot balanee the general loss. Others who have not failed, have still been great losers by the loss of trade. The working classes who consume the produce of the barn and the dairy have been the greatest losers of all. Where $1 l$. per week was paid for wages to machine-makers, only 11 s. $6 d$. is now paid; but the greatsot loss is in the want of work, even at these rednced wages.

LE1GH, a town in Lancashire in the cotton manufacture. Population, 26,588. Two fretories unemployed; five working short time; 4,000 looms without work; and the wages of those employed reduced 20 to 25 per cent. 
LonDos. - In the distriets of Spitalfields and Betlinal Green the trade is chiefly silk weaving. Wages are reduced 25 per cent, since 1836. Seven thousand looms are unem* ployed, and the number of persons ifle, with those depending on them, is 24,000 . Of tailors, there are 9,000 out of employment. All other trades are in a similarly prostrate condition. In the parish of Marylebone the expenditure for the rclief of the poor was in $1836,44,573 l . ;$ in 1840 , the sum was $76,354 l$.

Leicestzr. - A large town in the hosiery trade. Population 50,932. The distress and want of employmeut has increased within the last few months, and is rapidly increasing. The stocking frames are the same now as many years ago; stcam machinery has had no influenee in reducing employment. In 1815, there were 16,000 frames in Leicestershire, now there are only 14,000 . Whereas in Saxony there were in 1815 , not more than 4,500 frames, and now there are 25,000 .

Manchestre. - The head-quarters of the Lancashire cotton trade. In one district 2,000 families were found without a bed amongst them, and 8,666 persons whose income is only Is. $2 \frac{1}{2} d$. n weck. In one street, 15 shopkeepers taken in succession, butchers, grocers, drapers, and other retail traders, state that their aggregate receipts previons to the last two years were $53,560 l$. per annum. Tn 1835 , seven bakers and flour-dealers effected sales to the amount of $870 l$. weekly. In 1841 , their sales were $700 l$. weekly. In 1835 , their purchases amounted to 540 sacks, at $32 \mathrm{~s}$. per sack. In 1841, to 264 sacks at 53s. per sack, being a falling-off of more than one half. In addition to the enormous reduction in the virtual wages, and the purchasing power of the operative classes, it las been calculated that the total amount of money-wages paid to the operatives engaged in the cotton manufacture throughott the Kingdom is $7,000,000$ less per aumm than it was five years ago. It has bcen satisfactorily proved that fixed capital, such as buildings, machinery, \&c., has fallen in value more than one half since 1836 .

Nottinghas.-Population, 53,080. Trade, hosiery. The number of persons relieved in the woek ending January 22, 1842, was 10,580, about one-fifth of the entire population. Wages have fallen 25 per cent. since 1836 .

Oцрнам, a town in Lancashire, in the cotton trade. Population, 42,593 ; nine-tenths of whom are cngaged in, or dcpendent on, manufactures. In 1836, the poor-rates were $2,968 l . ;$ in 1841 , they were $7,682 l$., an increase of nearly 200 per cent. The number of persons fully employed, is 9,500 ; the number working half time, 5,000 ; and the number totally without work, 5,000 . The number of untenanted houses is about 1,200 .

Pontrzoos, and the Iron Trade generally.-At Tallywean, near Pontypool, of fourteen furnaces, five only are in blast, and all the mills where the iron is manufactured have beon stopped. In Poutypool, the population lias been rcduced, in two years, from 17,000 to about 14,000. The sum levied for relief of the poor has increased 100 to 150 per cent. At Weat Bromwich, the population is 43,902 , and wages have been reduced 25 per cent. since 1836. In Scotland, out of 83 blast furnaces that were in operation in 1841, there are now only 63 at work. The number of hands thrown out of work is about 6,000 . The reduction of wages to those employed amounts to above 10,000l weekly. In all directions the iron trade is suffering to the same extent.

Роттвлтвs.-A district of Stafiordshire. Population upwards of 70,000 , all depending on the ehina and earthenware trade. For the last two or three yeass the trade has suffered an unexampled depression. Although the manufacture is carried on almost entirely by hand-labour, thonsands of workmen are reduced to short time, hundreds are absolutely without work. Shopkeepers are becoming bankrupt, and the consumption of the better kinds of food is fast declining.

PAPBR TRADE. - The number of mills throughout the south of England is about 300, and of these only 120 are in operation.

PArsrex.-Population is about 60,000 , chiefly employed in the shaw manufacture and cottonspinning, the shawls by hand labour. One-third of the population is now dependant for support on charitable contributions. In February, 19,035 were thus relieved; and while this is being written (November 1842), the distress is on the increase, trade on the decline, and charity all but exhansted. During three wecks last year, 30 houses failed, whose engagcments amounted to $500,000 l$, and since last Midsummer two thirds of the manufacturers have become insolvent. The consumption of animal food and wheaten bread has entirely ceased, and the meanest kinds of diet resorted to. When tratle was good, a Paisley weaver could easily earn from 20s, to 30 s, a week

Prescor, a town near Liverpool, in Lancashire. Population 6,000; chiefly employed in watch-making. Six years ago about 2,000 hands were employed in the watch trade; now there are not more than one-third of that number. Wages have been reduced within 
that period about 50 per cent.' No introduction of steam nor machinery has taken place in this branch of industry.

Rochdalk,-A town in Lancashire, in the cotton trade. Popplation 24,423. The consumption of butcher-meat has fallen off one-half since 1836 .

Ripos, - A town in Yorkshire, in the flax manufacture. One mill which lately employed 40 men, 20 women, and 100 boys and girls, is now closed; two others which employed 100 hands each are closed; and wages of people in work are much reduced. The consumption of butcher-meat less by one-half than in 1836 .

Srroud.-In the West of England, broad cloth trade; and all the districts similarly employed in Devon, Somerset, and Gloncester are in a prostrate condition. The workpeople are either in the workhonse or living on food of the coarsest description. It is cstimatod that the capital invested in the woollen-trade is $10,000,000 l$, three-fourths of which is either lost, or at the present time rcalising no profits.

Sтоскрогт, a town in Cheshire engaged in the cotton trade. Out of 15,825 persons visited, there were 8,215 able to work, and of these 4,145 were unemployed; 2,866 partially employed, and only 1,204 fully employed. In July, August, and September 1835, the cattle sold in Stockport to the butchers were 814 ; in the same months of 1842 , the numbers 194.

Shurp18id, a town in Yorkshire. Population 85,076, chiefly employed in the hardware and catlery trade. Wages have fallen 40 per cent. since 1836 . Five-eighths of the goods manufactured in this town were for the United States; nearly one-half of that trade has been lost within the last few years. The consumption of flour, butcher-meat, butter and bacon has fallen off in the same time fully onc-half among the working class, and has been considerably reduced among shopkecpers and other traders, to the great injury of our corn-growers and grazicrs:

Stourbridge, Warrington, St. Helisns, aud other places in the glass-trade, are in a fearful state of suffering.

$W_{t G \Lambda N}$, a town in Lancashire, in the eotton trade. Of persons visited 4,109 were incapable of labour; 981 in full employment; 2,572 partially employed; and 1,563 ablebodied and unemployed. The average wages of those in full employment were $7 s .01 \mathrm{~d} d$. a week; of those partially employed, 4s. $3 \frac{1}{2} d$. a woek. Dedncting rents for looms, and adding the allowance of parish relief, the average income of the whole number was $18,7 \frac{3}{6} d$. per head a week, or $2 \frac{3}{6} r l$. per day, which, at that time, if wholly laid out in bread, would be $1 \mathrm{lb}, 6 \mathrm{oz}$. for each, and nothing more. There were 2,745 who slept three in a bed; 1,852 , four in a bed; 830 , five in a berd; 503 , who slept six, seven, and eight in a bed; and there were many who had no beds at all. Of these beds a great many are very inferior, made up of straw, shavings, \&c.; great numbers have no bed-clothes; some sleep in their clothes; others take them off for a covering at night, having been obliged to plealge their bed clothos for subsistence; great numbers have no change of linen, and many have no linen at all. Loaf-breal, butcher-meat, butter, cheese, or bacon, are entirely beyond the reach of this hunger-stricken people; yet at no distant time they were consumcrs of all these, and it is possible by certain changes in the laws affecting trade they may be so again.

Wolverhampton, a town in the hardware trade, near Birmingham. Prices have fallen 30 to 40 per cent. since 1836. During the last hundred years the consumption of iron in thistowu has increased from 17,000 tons a year to $1,500,000$ tons; but owing to the depression of trade the iron-masters have rednced the mauufacture 25 per cent., or 400,000 tons, throwing many people out of work, and reducing the wages of the others. The consumption of butcher-meat has greatly decreased within the last year.

Westrunx.-A town in Wiltshire. Trade, woollen cloth. Three hundred and twentytwo looms employed; 354 unemployed.

$\mathrm{Y}_{\text {rovri, }}$ a town in Somersetshire, in the glove trade. Population 7,000. No steam nor machinery are employed. A large number of the population has been for some time withont work. The sum levied for the poor is 100 per cent. higher than it was seven ycars ago. The consumption of the better kinds of food has materially fallen off within the last two years.

Such is the condition of the manufacturing towns from which accurate returns have been received. We have not mentioned Glasgow and its neighbourhood, where the manufacturing interests and the population are so great, and the blow which trade has received so stunning-laying prostrate the most prosperous and industrious of masters and men-that those employed 
is collecting facts have not, at the period of printing the reports already quoted, been able to grapple with that great city's misery and misfortunes.

Neither have the great shipping interests of the ports of London, Liverpool, Bristol, Hull, Newcastlc, Dundee, Aberdeen, Greenock, \&c., been introduced separately; but wc come now to a statement which relates to the shipping interests and also to the interests of the English farmer. The total number of registered ships bclonging to the British empire on the 31 st of December, 1838, was 26,609, and on the 31st of December, 1839, 27,745. These do not include the fishing craft nor barges, canal boats and such like with which our coasts and inland waters are swarming when trade is good. Nor does the number give a correct idea of our shipping trade, inasmuch as upwards of 9,000 foreign ships entered our ports during that year. But it shows an increase of 1,136 registered ships in one year of fair tradc, to be contrasted with the present year, when shipbuilders are not only uncmployed, but one-third of all the ships in our harbours are offered for sale without purchasers being found, in one case out of a hundred, to offer for them the prices of 1838. In the vast docks of Liverpool and London and Hull the vessels are crowded with a broom at the mast head (the signal of "for sale"), as was never seen since these docks were formed. If a British grazier and corn-grower will reflect for a few minutes on the non-consumption of sea stores, becf, pork, biscuit and flour, which this choking up of our docks with unemployed ships oceasions, he will sce an additional weight of evidence to explain the causes of his dull markets, which, if not speedily removed, will increase in weight until it falls upon him with the force of unavoidable destruction.

It is hardly possible that a farmer can have read the preceding details of stagnant trade without apprchending that therein is the cause of his decreased profits. But we must present another view of that relationslip which exists between agriculturc and general trade, between the manufacturers of corn, butcher-meat, butter and cheese, and the manufacturers of clothes, furniture, and ships.

It is a fact, clearly ascertained, that population increases in all nations according to the demand for human labour. So long as England was merely an agricultural country, her population, like her agriculture and the demand for labour, advanced very slowly. In 1696 , just 146 years ago, the population of England was about 5,500,000. In 1760 it had only increased about one million. It advanced with greater speed, though still slowly, from that time to 1801 , at which period it was $8,872,980$, during which period manufactures had increased in the same proportion. In ten years afterwards, in 1811 , the amount was $10,150,615$. Ten years after that, in 1821 , the amount was $11,978,875$. Ten years after that, in 1831 , the amount was 13,894,569. And ten years after that, in 1841, the amount was 15,906,829; Scotland and Ireland having increased in the same proportions. In the manufacturing districts the increase has been 22 per cent., while in the agricultural districts the increase has been but $10 \frac{1}{2}$ per cent. In 1831 it was calculated that one-third of the entire population of the united kingdom lived in towns containing upwards of 10,000 inhabitants each. But not only have our manufactures and trade caused our population to be doubled during the last forty years, but they have called forth a productive power of machinery during the same period equal to fifty millions of men. Some of you may think, or thoughtlessly say, this increase of machinery is an evil. But you must not suppose that an additional fifty millions of working persons would have had employment had they, and not machinery, existed. It is the machinery that has called forth the great increase we already have, which 
great increase of consumers has increased the value of farm produce. In the year 1787 , when the machine commonly called the spinning-jenny came first into common use, the manufacturers paid for their fine yarn twenty guineas pcr lb. Of latc years when our trade was good, say in 1836 , the same quality of yarn was sold for $15 \mathrm{~s}$, per $\mathrm{lb}$. The cotton twist, which sold in 1786 for 11. $18 s$. per lb. was sold in years when trade was prosperous for $3 s$. But this, instead of showing a decrease of national wealth, shows an enormous increase. If the price was twenty times higher seventy years ago than now for a certain article, that article is produced to scveral hundred times the amount now that it was seventy years ago. Were it not for overloading the mind and distressing the eye of the reader with figures, we might quote from tables furnished by the Board of Trade in proof of this. But it is needless to prolong this branch of evidence. Let us proceed to another; and lest some reader, already distressed with figures, should skip over them, we shall here give him the sums which affect the farmer's profit and loss in words.

The cotton trade alone employs one million five hundred thousand persons. It is not easy to state what the arerage wages of the weavers are, the wages of the young varying from $1 s$. $6 d$. to $7 s$. a week, of women from $8 s$. to $15 s$, of men from $13 s$. to $25 s$. in the mills; while weaving by the hand is considerably lower priced. But if we include the wages of engineers, smiths, and others engaged in the works, who are of course included in the million and a half of hands, we shall be as nearly correct as we can be in stating a round sum, if we say the amount of wages paid by the cotton manufacturers is thirty-seven millions and a half sterling, a year! If from this we deduct only twenty per cent. (we might deduct more and be within the truth) for the reduction that has taken place since the years of manufacturing prosperity, we shall have a loss of seven millions and a half, leaving thirty millions for wages, supposing the whole of the factory people to have full employment. But to the loss of seven millions and a half, by wages reduced, we must add one-fourth of the remaining thirty millions, or twenty-five per cent. of that sum for workpeople unemployed; and as the fourth part of thirty is seven and a half, we have another loss of seven and a half millions, which with the former loss makes fifteen millions of pounds sterling. We shall be told, though not correctly, that the whole of the million and a half of hands were never all employed and receiving wages at once, and that overseers of mills, principal clerks, and so on, are in some cases receiving the same salaries now as formerly. But against this, were the objection truly founded, we have a set off, namcly, that while we have stated the number of the unemployed to be one-fourth, or twenty-five per cent., or, more plainly speaking, twenty-five to the hundred, we would have been within the truth in stating it at thirty five to the hundred, which would have shown an additional loss fully equivalent to the contingencies that may be urged against us.

Lct us now examine into the expenditure of wages by those employed in the cotton-working districts.

A man, his wife, and four children, whose earnings amount only to $5 s .6 d$. a week, expend it in the following proportions, the averages are taken from a large number of families:-Bread and flour, 1s. $9 d$.; oatmeal, 1s.; potatoes, 10d. ; milk, 11d.; butter, nothing; butcher-meat, nothing; bacon, $2 d$. ; cheese, nothing; ale or beer, nothing. Total 4s. $8 d$. for articles directly furnished by British farmers. Of exciseable articles, they purchase soap and candles to the value of $4 d$., which makes five shillings; they have still a sixpence, and this goes for coals, leaving nothing for sugar, treacle, tea, coffee, tobaceo, snuff, medicine, clothing, education, sick socicties, rent, or other expenses incidenta: and necessary to a family. 
The next family we shall take contains the same number of persons, namcly, husband, wife, and four children. Their carnings are $10 \mathrm{~s}$. a week. They give for bread and flour, $2 s .6 d$. ; oatmeal, 1s. 10d.; potatoes, $18.8 d$. ; milk, $6 d$.; butter, nothing; butcher-meat, nothing; bacon, $8 d$. ; cheese, nothing; ale or beer, notling. In all, for articles directly produced by our own farmers, $7 s .2 d$. a week, which is $2 s .6 d$. more than the other family pays. The remainder of their outlay is:-For sugar and treacle, $5 d$.; soap and candles, $6 d$; tobacco, snuff, or other condiments, $2 d$; clothing, $6 d$. ; coals, $9 d$. ; rent, $6 d$.

Next we have the same numbers in a family earning $15 s .6 d$. a week :-

They expend on bread and flour, $3 s .6 d$. ; oatmeal, 1s. $6 d$.; potatoes, 1s. $9 d$. ; milk, $9 d$.; butter, $10 d$.; butcher-meat, $9 d . ;$ bacon, $4 d$. ; and cheese, $7 d$.; making in all for Enghish produce, 10 s., being $5 s .4 d$. more than the sum expended on the same by the first family; and $2 s .10 d$. more than the second. The remaining expenditure of this third family is:-For sugar and treacle, $11 d$. ; tea and coffee, $7 d$.; soap and candles, $8 d$. ; tobacco, snuff, or other condiments, $4 d . d_{*}$; clothing, $9 d_{.}$; sick societies, $6 d$. ; coals, $9 d_{\text {. }}$; rent, $1 s$.

Next, and lastly, we have a family earning $26 s .6 d$, a week. The expenditure here is, for bread and flour, $4 s$. ; oatmeal, $2 s . ;$ potatoes, $1 s .8 d$. milk, $10 d$. ; butter, 1 s. $4 d$. ; butcher-meat, $1 s .9 d$. ; bacon, $3 d$. ; cheese, $10 d$. ; and ale or beer, $6 d$. In all, for home produce, $13 s .2 d$; being $3 s .2 d$. over the third, 6s. over the second, and $8 s$. $6 d$. over the first family. The remaining expenditure of this fourth family is:-For sugar and treacle, $1 s .9 d$; tea and coffee, $1 s$. $2 d$.; soap and candles, 1s.; tobacco, snuff, or other condiments, $11 d$.; medicine and attendance, $4 . d$. ; clothing, $2 s$. ; education, $6 d$. ; sick societies, $6 d$.; coals, $1 s .4 d$.; rent, $2 s .6 d$.; savings, $1 s .4 d$.

When trade was in a thriving condition, by far the greatest proportion of families belonged to this fourth class, a smaller proportion to the third, and comparatively few to the second or first. Now, in 1842, when trade is prostrate, the greatest proportion of families belong to the first and second classes, and comparatively few to the third and fourth.

We shall present the difference to the farmer in another shape.

There are about 250,000 tenant-farmers in Great Britain; and there are $1,500,000$ people employed in the cotton manufacture. Allowing to each of these persons, on an average, the burden of one individual not able to earn anything, we shall have three millions of a cotton-working population. This must be considerably too low, but we shall adhere to it. Divided into families of six persons each, this will give half a million of families; which gives two cotton-working families to each farming-tenant. Now, we have seen the difference expended in home produce between the four classes of families to be $2 s .6 d . ; 2 s .10 d$. and $3 s .2 d$; we have seen that' between reduced wages and unemployed people each family, to say the least, has come down two steps; the second and third classes being now in the first, and the fourth being down to the second, thus showing an average loss of $5 s .8 d$. for each family. But as there are two families to each farmer this must be du ubled, which makes $11 s .4 d$. a week, or $29 l .11 s .4 d$. a year, or in the whole $7,366,666 l .13 s .6 d$. to the landed interest.

If it is objected that this does not come direct to the farmers, but that it comes through the hands of bakers, millers, butchers, cattle dealers, and so on, who each have a profit out of it, we must remind the objector in return that these intermediate dealers are themselves, with their families and servants, consumers of the produce in which they deal. But more especially we must state that there is still a sum of more than seven millions and a half 
sterling, not now spent, but which, with wages in a healthy state, would be spent on exciseable articles, as sugar, tea, coffee, soap, candles, tobacco, snuff, medicine, \&c.; and on clothing, education, sick societies, fuel, rent, and other family necessaries. The consumption of which causes the employment of ships and sailors; insurance offices, merchants, clerks, porters and shopkeepers, who are all, with their families, and tailors, shocmakers, drapers, \&c., whom they deal with, consumers of farm produce.

We have already mentioned the shipping trade as being depressed in an unexampled degree. Wc may now remark before quitting the cotton-trade, that in addition to the falling away of the consumption of those foreign commodities which make up the trade of our shopkcepers, and which, in better times employs so many ships, therc is the greatest proportion of all the ressels usually bringing home raw cotton and taking away manufactured goods now laid up in the docks idle. The following account of one establishment in Manchester will give the rural reader some idea of the consumption of rav material, when a factory is in full work; we copy from an anthentic statistical account of Manchester:-

"The mill of Messrs. Birley and Co. consists of a group of brildings upon which, including machinery, seteral hundred thousand pounds have been sunk. The number of hands employed by this firm is 1,600 , whose wages annually amount to the sum of $40,000 \mathrm{l}$. The amount of moving power is equivalent to the labour of 397 horses. The number of spindles in the mill is about 80,000 . The annual consumption of raw cotton is about $4,000,000$ lhs. weight! The annual consumption of coal is 8,000 tans! It will, perhaps, excite surprise in a person unacquainted with the nature of machinery, when informed that the annual consumption of oil for the purpose of oiling the machinery is about 5,009 gallons, and the consumption of tallow for the same purpose $50 \mathrm{cwt}$. The annual cost of gas is $600 l$. One room alone, belonging to this firm, contains upwards of 600 power-looms, Besides the hands engaged in the cotton departmont, the following description of workmen are employed in this mill :--millwrights, mechanics, joiners, bricklayers, plumbers, painters, moulders, tumers, and smiths. The establishment in which the fabric is manufactured for waterproof clothing, such as 'Macintosh cloaks,' belongs to Messis. Birley and Co. The number of hauds employed in this business varies from 202 to 600 . The immense amount of $250,000 \mathrm{lbs}$. weight of India rubber is annually consumed in the process of manufacture, to dissolve which 100,000 gallons of spirits are employed."

Next to the cotton manufacture the woollen stands in importance. The reduced wages and unemployed people in this trade affect the farmers in the same way as those in the cotton trade. But the evil to the British farmer does not stop where that of the cotton trade stops. The raw cottou comes from America, Fgypt, and India; the raw wool is the produce, to a greal extent. of our own country. Six millions is paid annually for wool by our manufacturers when trade is thriving; when trade is dull much lcss wool is consumed and much less money paid. That such is the case this year our sheep farmers lnow to their serious loss. It therefore behoves them to consider how far they are dependant on a gqod manufacturing trade.

The silk manufacture may be reckoncd next. After it the leather manufacture, then the iron, cutlery, and hardware. And lastly the earthenware, china, and glass; with many minor and miscellaneous trades too numerous to
mention.

It only remains to be stated that to whomsoever the additional moncy for an increased consumption of agricultural produce may be paid in years of good trade; on whomsoever the loss by a reduced consumption may fall in years of bad trade, whether on tenant-farmers or landowning farmers, English, Scotch, or lrish, there is this year a sum paid for provisions of home produce less by forty millions sterling, than in a year of good trade. The entire value of our farm produce is estimated on an avcrage of years at

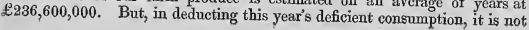


enough to estimate the mere operatives in our manufacturing towns. Vast numbers of families there, and in every village of the united kingdom, are reduced to the most rigid economy; they eat less bread and meat and butter and bacon and cheese, drink lcss beer, and use a lcsser quantity of exciseable articles. We do not openly see it, because they pinch themselves with this economy to hide their poverty.

Onoe more we assert, after careful calculation; that there is this year a reduced consumption of British agricultural produce to the amount of at least $40,000,000 l$. stcrling, which is to each farmcr, allowing for 10,000 who may cultivate farms of their own, in addition to the 250,000 farming-tenants, a sum of one hundred and fifty-three pounds, sixteen shillings, eleven-pence, and a fraction. Let the large farmers take to themselves the proportion of this which is not due to the small farmers, and they will find their present losses accounted for without needing to blame the New Tariff. And if anything is said of Irish provisions and Irish farmers in reference to this calculation, let it be remembered that the falling off in the consumption of sea stores, and the additional consumption of home produce which would accompany an increased use of forcign commedities, is not estimated in these forty millions. This sum is to be subtracted from the direct purchasers of home grown food made by those not able to buy to their usual amount; from the purchases made by our working poor whose poverty is visible, and by those a little above them in society whose poverty is as yet invisible, but not the less certain.

If it is asked, on reading this statement, why the effect of reduced consumption was not more immediately felt; why, as the manufacturing distress was so extensive in 1841 , the cattle and corn maintained their prices until the summer and harvest of 1842 ? this is my answer :-

1st. That many people struggled on for a time in the purchase of food, by disposing of their clothes and furniture, and by expending thcir little savings.

2nd. That farmers, dealers in cattlc, and others, held back their stock from market when they felt a threatened depression of prices, until the passing of the New Tariff alarmed them, and they sought safety in sending to market more stock than they would have done if tranquil and secure. Also the drought of the summer of 1842 increased the disposition to sell live stock when it was seen that autumn was approaching and still there was no rain to increase the parched vegetation. In short, the New Tariff produced a panic, as all changes in a protective duty must do, and the markets being in an unhealthy state, the panic kindled the slumbering disease, and the priccs fell.

$3 \mathrm{rd}$. The corn prices did not fall in proportion to the reduced consumption of bread and flour, becanse at no time is there a sufficiency of lomc-grown corn for consumption; because in 1841 , and beginning of 1842, there was more than an ordinary scarcity; and because the object of the corn-law is to perpetuate that scarcity. This it cffects up to a certain price, and up to a certain month of the year. It was the sliding-scale that for a time concealcd the truth of a reduced consumption, and all at once revealed it to the loss and dismay of the British corn-grower. If all the ingenuity of the most subtile minds was taxed to producc a law by which-prices of corn would be insettled, nothing could be devised to work more effectually for that insanc purpose than a sliding-scalc. Uneertainty is its very cssence. An artificial scarcity, followed by a whclming quantity of foreign corn poured in to the market in one week, or even one day, is the only certain attribute it posscsses. The speculator in foreign grain holds it back to the last day on which he can hope for a higher price and a lower amount of duty. All his arts and smal devices, and oftentimes monstrous frauds, are resorted to for raising the corn markets at the latter end of summer. The more unfavourable the season. 
for the British farmer, the more favourable it is for the importing speculator; the prices will be higher and the duty less. The home corn-grower prays to God for good weather and good crops; the foreign corn-importer prays for as much good weather as will bring his ships safe to shore, and as much bau weather after as will retard or destroy the British crops. Our farmers rejoice in the prices as they mount up, and the higher the figures mount the happier are the farmers. They, and the sliding-scale speculators go thus far, hand in hand, during the summer, but they separate entirely in August. The speculator, having reached the high price, pays the low duty and the market is inundated. The farmer having helped him, by rejoicing in the high price and voting at elections for the makers of sliding-scales, sees the market suddenly depressed, and sells his corn for fifty instead of seventy shillings a quarter.

What avails it that the spcculators are sometimes ruined, and that the farmers are sometimes saved? Gamblers only return the more eagerly to. a gambling-table when they have been losers, in the hope of being more successful. So is it with spcculators in the sliding scale; while the British farmer gains nothing in the years ho is not injured, his rent is estimated from a scale of high prices, and that rent he must pay, though left to the gambling cluances of the importing speculator.

A fixed duty would have a tendency to regulate prices, but it would not reanimate our trade, on which our farmers are now wholly dependant for the consumption of their produce, neitber can it be enacted as a final measure There never can be safety and security to the British farmer but bi a total repeal. Then, and not till then, can he venture to take a lease of 1 and until he has a lease, he never can cultivate well: All the ag? societies and speches of landowners urging tenants to improve their $f_{1}$ utterly valucless so long as there is neither a lease to secure the prut expended capital to the farmer, nor a regularity of prices on which the $\mathrm{jr}$. rent for a lease can be calculated.

A second letter, published as this, will show how our manuf, trade will be restored; and how the farmer will be able, to compete n safety and success against the foreign corn-grower. This adaz: only intended to show the intimate relationship existing between 5 agriculture and British manufactures, and to prcpare the farmer for to consideration of those changes now rendered absolutely necessary \& sa. land and landlords, cultivation and cultivators, trade and traders, labour an labourers, from ruin.

Postscrips.-While the foregoing was in the hands of the printer, the deficiency in the quarter's revenue has been announced by the frovermment: a deficiency equal to three millions and a half sterling a year, chiefly cansed by a falling-of: in consumption, tl rough the inability of the factory workers to purchise exciseable artioles as nsual. If trade is rot revived the deficiency will increase; the farmers will be called on to pay their share, a in revived the deficiency will increase; the Income-tax, to make np the delieieney; and this will again, for the sake of economy, eanse still less to be consumed. The first falling-oif in consumption lavir. begun with the working people, it will soon fall off in the bouses of the master employers

Second Postscript.-Previons to the appenrance of the second Yetter, perhaps th farmer who reads this will ask himself the following question:- If my ehildren increase in number, if the number of farms remain the same, and if trade does not revive in the towns, what am I to do with my sons?

B. D. Cousins, 18, Duke-street, Lincoln's-inn-field's, 
SOUTHAMPTON UNIVERSITY LIBRARY

Date of Issue

$\mid$

Printed image digitised by the University of Southampton Library Digitisation Unit 


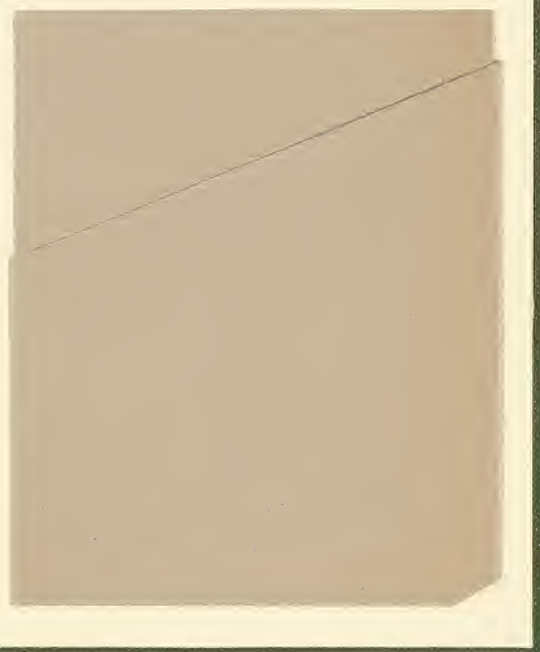

Printed image digitised by the University of Southampton Library Digitisation Unit 


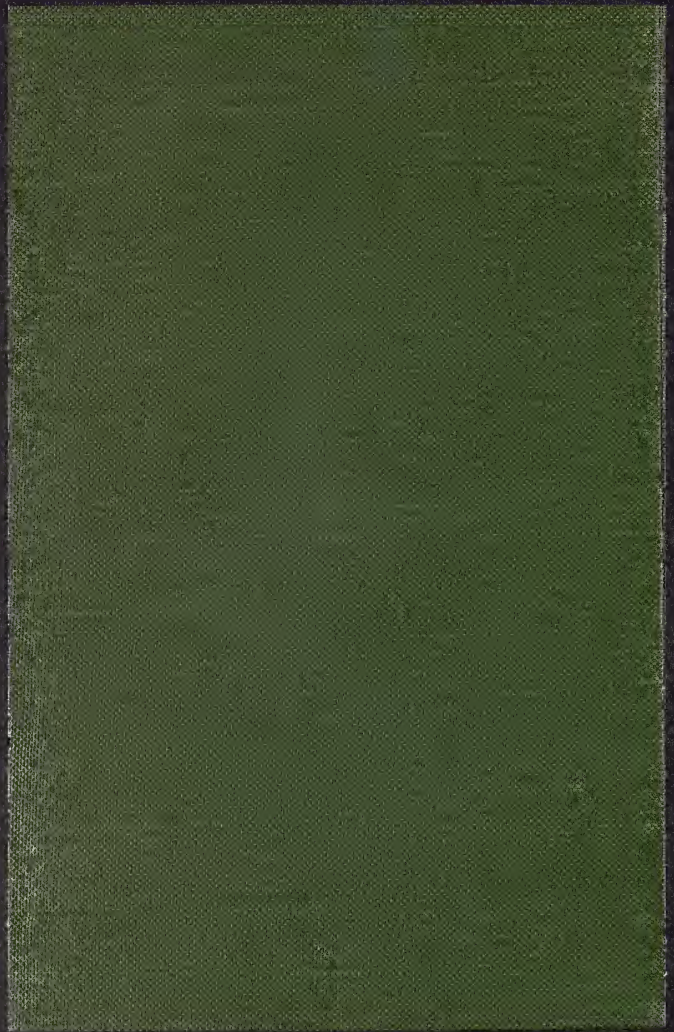

Printed image diqitised by the University of Southampton Library Diqitisation Unit 
towing

yoth

cingt

tis?

tores

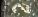

$-100$

as

todes

$\mathrm{As}$

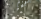

$4 x^{2}$ 